\title{
Relationship between oxygen radical absorbance capacity (ORAC) index, body composition and blood biochemical markers in overweight /obese compared to normal weight subjects: a cross- sectional study
}

\section{Zahra Madani \\ Islamic Azad University Science and Research Branch \\ Maryam sadat Mousavi javardi \\ Islamic Azad University Science and Research Branch}

Seyyed abolghassem Djazayeri

Tehran University of Medical Sciences

Ariyo Movahedi ( $\square$ amm35@mail.aub.edu )

Islamic Azad University Science and Research Branch

Majid Karandish

Ahvaz Jondishapour University of Medical Sciences

\section{Research article}

Keywords: Oxygen Radical Absorption Capacity (ORAC), Lipid Profile, Fasting blood Glucose, Obesity, Overweight

Posted Date: June 3rd, 2020

DOI: https://doi.org/10.21203/rs.3.rs-31628/v1

License: (c) (i) This work is licensed under a Creative Commons Attribution 4.0 International License.

Read Full License 


\section{Abstract}

Backgroumd: Obesity is an important preventable disease, which promotes the development of chronic disorders by altering several factors including oxidative stress. Dietary antioxidants protect the body against oxidative stress. The purpose of this study was to evaluate the potential association of oxygen radical absorbance capacity (ORAC) index with obesity and its associated features in adults.

Methods: participants were divided in two groups of normal weight and overweight /obesity. General characteristics were registered and a 147-item food frequency questionnaire was completed. Thereafter, anthropometric measurements were conducted. Biochemical indices were obtained from science and Research branch of Islamic Azad University of Tehran, Iran. The amount of the dietary ORAC index was estimated using the data provided by the USDA Foods Table.

Results: The results showed that there was a significant difference between the normal and overweight/obese groups in terms of body mass index (BMI) and waist-to-hip ratio (WHR) ( $P=0.0001)$. Participants with normal weight consumed more fruits and vegetables than another group. Also, the dietary ORAC index in normal individuals was higher than the case group, but there was not significant difference $(P=0.352)$. There was also a significant inverse correlation between dietary ORAC and $B M I$ and WHR, whereas a significant positive correlation between dietary ORAC and plasma HDL was observed $(P<0.05)$.

Conclusion: Our findings suggest that dietary antioxidants is inversely associated with BMI, fasting blood glucose, triglyceride, total Cholesterol and LDL in both groups. It seems that following a diet rich in antioxidants can counteract obesity and its associated comorbidities.

\section{Background}

Obesity is a complex and multifactorial disease with a high prevalence around the world [1,2]. The worldwide prevalence of overweight and obesity has doubled since 1980 and about a third of the world's population is classified as overweight or obese [2]. At least 2.8 million deaths worldwide are related to obesity and overweight and the prevalence of the disease is increasing annually. The disease results from complex phenotypes associated with excess fat in the body that affect other metabolic factors in addition to body size [1]. Obesity is associated with numerous disorders, including diabetes, lipid profile abnormalities, liver disease, immune dysfunction and oxidative stress [3-5].

Oxidative stress is defined by excessive endogenous oxidative species; especially reactive oxygen species (ROS), such as superoxide, hydrogen peroxide and hydroxyl radical ions which damage cells and manipulate signal pathways [6,7]. Fat accumulation stimulates lipid peroxidation and damage caused by free fatty acids and cytokines, such as TNF-a, leading to the exacerbation of the oxidative damage [8]. Subjects with obesity and metabolic diseases have also shown lower levels of antioxidant activity [9]; additionally, studies have shown that obesity increases the risk of metabolic syndrome in obese and overweight people due to increased oxidative stress $[5,10,11]$. On the other hand, oxidative stress disrupts 
insulin secretion from pancreatic beta cells [12] and induces insulin resistance [13], as well as impaired glucose transport to the muscles and the adipose tissue [12]. Hyperglycemia produces alterations in various metabolic and cellular functions; including dyslipidemia, hypertension, endothelial dysfunction, and oxidative stress $[14,15]$.

In recent years, antioxidants have been used to overcome the harmful effects of ROSs. Natural antioxidants found in healthy foods, include vitamins E and C, coenzyme Q10, alpha-lipoic acid, lycopene, and polyphenols [16].The results of the studies indicate that there is an inverse relationship between body fat, central fat and antioxidant capacity [17].

Various methods are available for measuring the dietary total antioxidant capacity (TAC) $[18,19]$. According to the United States Department of Agriculture (USDA) database, the oxygen radical absorbance capacity (ORAC) index is an indicator that measures the antioxidant power of foods and other chemicals in the laboratory, and it is a preferable method because of its biological relevance to the in vivo antioxidant efficacy [20]. Recent studies have shown that fruits and vegetables with high ORAC, such as spinach and blueberries, prevent chronic diseases [20-22].

Since oxidative stress, directly and indirectly, causes many diseases, including obesity and metabolic syndrome, the purpose of the present study was to investigate the relationship between the dietary ORAC index and fasting blood glucose and lipid profile in overweight or obese subjects compared to normal weight subjects.

\section{Methods}

\section{Study Type and Participants:}

This study was a cross-sectional descriptive-analytic case-control study. It was carried out to show how antioxidant power of foods effects on anthropometric and biochemical parameters. The subjects were normal weight and overweight/obese adults who were randomly selected among the staff of Science and Research branch of Islamic Azad University (SRBIAU) clinic of Tehran. All the basic required information, including BMI and the latest blood test, was available in the University Electronic Health Clinic Database. After choosing possible eligible samples from the main data bank, some of the staff members were invited to volunteer in this study. Atleast 70 individuals in each group were considered to participate in this study who has $\mathrm{BMI}>18.5$ and age ranged between $18-65$ years. All volunteers should not be under lipid and glucose control drug or be pregnant. All as well as unwillingness to cooperate during the study indicated by leaving more than $50 \%$ of the questions in the food frequency questionnaire (FFQ) unanswered.

\section{Study implementation:}


This study was approved by the ethical Iran National Committee for Ethics in Biomedical Research under code IR.IAU.SRB.REC.1396.66. All the eligible volunteers were informed about the details of the study and written consent were taken. On the day of referral to the SRBIAU Clinic, information about demographic characteristics was obtained through face-to-face interviews using validated questionnaires.

Anthropometric measurements, including weight and body composition, were conducted using the bioelectric impedance analyzer (INBODY, Model 270, South Korea); height was measured using a digital freestanding stadiometer (BSM-170, InBody Co. Ltd, South Korea). Dietary assessment was also carried on using a validated semi-quantitative FFQ containing 148 food items [23].

\section{Foods' ORAC measurement:}

Dietary antioxidant consumption was estimated based on the ORAC index of selected foods reported by the Nutrient Data Laboratory of USDA, and expressed as $\mu \mathrm{mol}$ of Trolox Equivalents per 100 grams of foods ( $\mu \mathrm{molTE} / 100 \mathrm{~g})[20]$.

\section{Statistical analysis method:}

Independent T-test or Mann-Whitney test (in the case of nonparametric data) were used to compare the mean of quantitative outcomes between the two groups. Correlation models were used to find out the relationship of the variables of the study. SPSS software version 25 was used for data analysis and Pvalue $<0.05$ was considered as statistically significant.

\section{Results}

In the present study, the relationship between dietary ORAC index with lipid profile and fasting blood glucose in obese/overweight population and normal weight population was examined. After calculating the sample size and simple random sampling, 220 adults, 110 overweight/obese and 110 with normal weight, were recruited based on the inclusion and exclusion criteria. Amongst these, 20 volunteers were excluded because of incomplete questionnaires (more than half of the items were not completed). Finally, the study was conducted with 100 normal weight and 100 overweight or obese subjects.

Basic information of two groups is presented in Table 1. As shown in Table 1, participants with normal weight had a lower visceral fat mass (five kilograms; $P<0.01)$ and a lower body fat percentage $(P<0.01)$. Waist to hip ratio (WHR) was significantly lower in the normal weight group as compared to overweight/obese group $(\mathrm{P}<0.01)$. As expected, fasting blood glucose $(\mathrm{FBG})$, total cholesterol $(\mathrm{TC})$, triglyceride (TG), and low-density lipoprotein (LDL) were higher in overweight/obese volunteers than normal volunteers were, whereas HDL was greater in the normal weight group; these differences were not significant. 
Table 1

Basic information of two groups

\begin{tabular}{|llll}
\hline Variable & Normal weight & Overweight/obese & P-Value \\
\hline $\mathrm{N}$ & 100 & 100 & \\
\hline Sex $(\mathrm{M} / \mathrm{F})$ & $70 / 30$ & $65 / 35$ & 0.824 \\
\hline Marital status (S/M) & $25 / 75$ & $45 / 55$ & 0.762 \\
\hline Age (year) & $40.50 \pm 8.976$ & $40.60 \pm 7.354$ & 0.915 \\
\hline & & & \\
\hline Anthropometric indices, mean \pm SD & & & $0.0001^{*}$ \\
\hline Weight (Kg) & & $95.05 \pm 12.32$ & 0.856 \\
\hline Height (Cm) & $70.13 \pm 9.33$ & $170.20 \pm 4.38$ & $0.0001^{*}$ \\
\hline BMl (Kg/m $\left.{ }^{2}\right)$ & $172.86 \pm 4.58$ & $31.28 \pm 4.16$ & $0.0001^{*}$ \\
\hline WHR & $23.58 \pm 1.52$ & $0.95 \pm 0.06$ & $0.0001^{*}$ \\
\hline Visceral fat & $0.090 \pm 0.04$ & $12.30 \pm 3.59$ & $0.0001^{*}$ \\
\hline Body fat mass (Kg) & $7.55 \pm 2.10$ & $28.77 \pm 7.48$ & $0.004^{*}$ \\
\hline Body fat percentag (\%) & $19.76 \pm 10.76$ & $3.14 \pm 2.77$ & \\
\hline & $2.14 \pm 0.78$ & & \\
\hline
\end{tabular}

\section{Biochemical parameters, mean \pm SD}

\begin{tabular}{lccc} 
FBG $(\mathrm{mg} / \mathrm{dl})$ & $89.01 \pm 10.73$ & $92.09 \pm 16.33$ & 0.175 \\
\hline $\mathrm{TG}(\mathrm{mg} / \mathrm{dl})$ & $152.52 \pm 85.38$ & $164.99 \pm 84.67$ & 0.362 \\
\hline $\mathrm{TC}(\mathrm{mg} / \mathrm{dl})$ & $172.17 \pm 35.30$ & $175.06 \pm 29.90$ & 0.580 \\
\hline $\mathrm{LDL}(\mathrm{mg} / \mathrm{dl})$ & $98.44 \pm 29.71$ & $100.22 \pm 25.75$ & 0.687 \\
\hline $\mathrm{HDL}(\mathrm{mg} / \mathrm{dl})$ & $44.51 \pm 8.41$ & $42.40 \pm 9.67$ & 0.151 \\
\hline $\begin{array}{l}\text { Abbreviations: BMl, Body mass index; WHR, Waist to hip ratio; F, Female; M, Male; FBG, Fasting blood } \\
\text { glucose; TG, Triglyceride; TC, Total Cholesterol; LDL, low-density lipoproteins; HDL, high-density }\end{array}$ \\
$\begin{array}{l}\text { lipoproteins. } \\
* P<0.05\end{array}$ & & \\
\hline
\end{tabular}

Dietary data analyses are presented in Table 2. The consumption of vegetable, fruits, vitamin C, and vitamin $\mathrm{E}$ was higher in the normal weight group than the other group; the difference was only significant 
in fruit consumption $(P=0.026)$. Moreover, the dietary ORAC index was higher in normal weight volunteers than the overweight/obese group; the difference, though, was not significant $(P=0.352)$.

Table 2

Comparison of dietary intake and ORAC in two groups of normal weight and overweight/obese

\begin{tabular}{|llll}
\hline Variable & $\begin{array}{l}\text { Normal weight } \\
(\mathbf{n}=100)\end{array}$ & $\begin{array}{l}\text { Overweight/obese } \\
(\mathbf{n}=100)\end{array}$ & P-Value \\
\hline Vegetable & $15.116 \pm 1.713$ & $12.426 \pm 1.284$ & 0.918 \\
\hline Fruits & $20.943 \pm 1.415$ & $14.246 \pm 2.702$ & $0.026^{*}$ \\
\hline Vitamin.C & $140.60 \pm 87.96$ & $123.07 \pm 74.85$ & 0.081 \\
\hline Vitamin.E (alpha.tocopherol) & $11.98 \pm 10.42$ & $10.45 \pm 9.44$ & 0.064 \\
\hline ORAC & $48002.65 \pm 14651.20$ & $14785.27 \pm 8149.51$ & 0.352 \\
\hline $\begin{array}{l}\text { Abbreviations: ORAC, Oxygen radical absorbance capacity. } \\
* P<0.05\end{array}$ & & \\
\hline
\end{tabular}

The correlation between the dietary ORAC index with anthropometric indices and biochemical parameters in the two groups are presented in Table 3. According to Table 3, ORAC index was inversely correlated with all anthropometric indices and biochemical parameters except for HDL. Significant correlation between ORAC with BMI, WHR and HDL was observed $(P<0.05)$. 
Table 3

Correlation coefficient between anthropometric indices and blood biochemical markers with dietary ORAC index

\begin{tabular}{|c|c|c|c|c|c|c|}
\hline \multirow[t]{2}{*}{ Variable } & \multicolumn{2}{|c|}{$\begin{array}{l}\text { Normal weight } \\
(n=100)\end{array}$} & \multicolumn{2}{|c|}{$\begin{array}{l}\text { Overweight/obese } \\
(n=100)\end{array}$} & \multicolumn{2}{|c|}{$\begin{array}{l}\text { Total } \\
(n=200)\end{array}$} \\
\hline & $\mathrm{CC}$ & P-Value & $\mathrm{CC}$ & $\begin{array}{l}\text { P- } \\
\text { Value }\end{array}$ & $\mathrm{CC}$ & $\begin{array}{l}\text { P- } \\
\text { value }\end{array}$ \\
\hline $\operatorname{BMI}\left(\mathrm{Kg} / \mathrm{m}^{2}\right)$ & -0.768 & $0.047^{\star}$ & -0.876 & $0.010^{*}$ & -0.831 & $0.036 *$ \\
\hline WHR & -0.796 & $0.042^{\star}$ & -0.869 & $0.023^{*}$ & -0.680 & $0.043^{*}$ \\
\hline Body fat mass (Kg) & -0.188 & 0.117 & -0.196 & 0.068 & -0.035 & 0.661 \\
\hline Body fat percentage (\%) & -0.083 & 0.489 & -0.201 & 0.062 & -0.012 & 0.879 \\
\hline Visceral fat & -0.094 & 0.435 & -0.172 & 0.111 & -0.071 & 0.377 \\
\hline FBG (mg/dl) & -0.041 & 0.734 & -0.008 & 0.938 & -0.033 & 0.677 \\
\hline TG (mg/dl) & -0.031 & 0.796 & -0.023 & 0.829 & -0.020 & 0.802 \\
\hline $\mathrm{TC}(\mathrm{mg} / \mathrm{dl})$ & -0.204 & 0.087 & -0.066 & 0.544 & -0.076 & 0.343 \\
\hline LDL (mg/dl) & -0.194 & 0.105 & -0.008 & 0.944 & -0.089 & 0.266 \\
\hline $\mathrm{HDL}(\mathrm{mg} / \mathrm{dl})$ & 0.773 & $0.049 *$ & 0.948 & $0.012^{*}$ & 0.890 & $0.034^{*}$ \\
\hline
\end{tabular}

Abbreviations: BMI, Body mass index; WHR, Waist to hip ratio; FBG, Fasting blood glucose;

TG, Triglyceride; TC, Total Cholesterol; LDL, low-density lipoproteins; HDL, high-density lipoproteins; $\mathrm{CC}$, Correlation coefficient

$* P<0.05$

\section{Discussion}

In the present study, we were able to show that the dietary ORAC index was higher in normal weight volunteers as compared to the overweight/obese group. In addition, there was an inverse relationship between the dietary ORAC index and anthropometric indices, FBG, TG, TC and LDL. To the best of our knowledge, this is the first study investigating the association between dietary ORAC index, body composition and plasma biochemical markers in both overweight/obese and normal weight groups. Previous studies have shown an inverse relationship between the consumption of dietary antioxidants and several outcomes such as stroke [24], hypertension [25], myocardial infarction [26], cancer [27] and mortality [28]. 
In the present study, the dietary ORAC index was inversely correlated with BMI. Excessive fat accumulation can lead to obesity [29]. With increased obesity, the extra stored fat increases the production of oxygen radicals and inflammatory factors, as well as cholesterol and blood lipids [30]. Excess calories inhibit the production of adiponectin [31]. In the short time, the body tries to modify these damaging anomalies, but in the long run the immune system's ability to function is attenuated and oxidative stress can damage cells. Additionally, increased secretion of leptin usually accompanied by obesity leads to activation of T-lymphocytes leading to the production of proinflammatory factors, such as interleukin-2 and TNF-a which in turn can cause inflammation and oxidative stress in the body [32]. The body responds to these changes by using natural antioxidants, such as vitamins $E$ and $C$. If the body is unable to eliminate these factors, excessive accumulation of oxidants can lead to impaired protein and fat function, cellular dysfunction and, ultimately, to inflammation $[5,33,34]$. Obesity-induced inflammation and oxidative stress increase insulin resistance[6] by reducing the expression of insulin receptor substrate-1 (IRS-1) [35]. As a result, promoting the body's antioxidant capacity can greatly prevent the complications of diabetes [36].

Consuming antioxidant-rich foods with a high capacity to absorb oxygen radicals will give the immune system a chance to counteract inflammation[37].Despitethe type of the present study as a short study, similar to the findings in the current study, the higher dietary ORAC index has been an indication of higher quality of the diet and was related to higher consumption of fruits and vegetables. The favorable effects of these antioxidant-rich foods on improvement of fasting blood glucose, lipid profile and obesity have been investigated in some pre-clinical and clinical studies[38-42]. In recent years, chemical antioxidants, such as "phytochemicals", are suggested as plausible candidates in the prevention and/or treatment of specific diseases, including obesity and obesity-related metabolic disorders [43].

Parallel with our findings, many studies have shown that the dietary antioxidant capacity of volunteers with normal weight is higher as compared to overweight/obese ones. In a study, Hermsdorff et al demonstrated that dietary antioxidant capacity was negatively and significantly correlated with waist circumference (WC) [17]. Also another study showed that high WHR is linked with increased oxidative stress [44]. Similarly, an increase in dietary antioxidant was shown to reduce the incidence of abdominal obesity [45]. In line with our findings, previous studies showed that obesity is related with unhealthy diet, which is full of carbohydrate, fat, simple sugars and sweet beverages, whereas a protective effect against obesity is observed in the consumption of a diet rich in fruits and vegetables $[46,47]$ and a diet high in vegetables and fruits has been positively related to the consumption of antioxidant vitamins [47].

The present study showed that there was an inverse association between the dietary ORAC index with FBG, TG, LDL and TC, whereas a positive correlation between ORAC and HDL was observed. As well as, Many studies have supported these findings [48-50]. Some studies have also reported that antioxidant capacity in obese and overweight volunteers is promoted which was postulated to be due to immune system's trying to override the present inflammation [51,52].

\section{Conclusion}


Our findings suggest that consumption of dietary antioxidant was inversely associated with BMI and other anthropometric measurements, FBG, TG, LDLandTC in both groups. It seems that following a diet rich in ORAC can counteract obesity and its associated comorbidities.

\section{Abbreviations}

ORAC, Oxygen radical absorbance capacity; BMI, Body mass index; WHR, Waist to hip ratio; FBG, Fasting blood glucose; TG, Triglyceride; TC, Total Cholesterol; LDL, low-density lipoproteins; HDL, high-density lipoproteins

\section{Declarations}

\section{Ethics approval and consent to participate}

This study was approved by the ethical Iran National Committee for Ethics in Biomedical Research under code IR.IAU.SRB.REC.1396.66. All the eligible volunteers were informed about the details of the study and written consent were taken.

\section{Consent for publication}

Not applicable

\section{Availability of data and materials}

The data that support the findings of this study are available from Science and Research branch of Islamic Azad University (SRBIAU) clinic but restrictions apply to the availability of these data, which were used under license for the current study, and so are not publicly available. Data are however available from the authors upon reasonable request and with permission of the clinic. In our contract between the clinic and us has been mentioned that they never give us the participant information because our data are a part of a great database. Even they have their own reliable statistics specialist who analyse our findings then we wrote the manuscript base on the results.

\section{Competing interests}

The authors declare that they have no competing interests" in this section

\section{Funding}

Not applicable 


\section{Authors' contribution}

ZM and MM wrote the manuscript. AM checked it for accuracy of English language. AD and MK were adviser and supervisor of the study.

\section{References}

1. WHO. 10 facts on obesity. World Heal. Organ. [Internet]. World Health Organization; 2017; Available from: http://www.who.int/features/factfiles/obesity/en/

2. Chooi YC, Ding C, Magkos F. The epidemiology of obesity. Metabolism. W. B. Saunders; 2019;92:610.

3. Jung UJ, Choi MS. Obesity and its metabolic complications: The role of adipokines and the relationship between obesity, inflammation, insulin resistance, dyslipidemia and nonalcoholic fatty liver disease. Int. J. Mol. Sci. MDPI AG; 2014. p. 6184-223.

4. Uranga RM, Keller JN. The Complex Interactions Between Obesity, Metabolism and the Brain. Front. Neurosci. [Internet]. Frontiers Media S. A.; 2019;13:1-21. Available from: https://www.frontiersin.org/article/10.3389/fnins.2019.00513/full

5. Manna P, Jain SK. Obesity, Oxidative Stress, Adipose Tissue Dysfunction, and the Associated Health Risks: Causes and Therapeutic Strategies. Metab. Syndr. Relat. Disord. [Internet]. Mary Ann Liebert, Inc.; 2015 [cited 2019 Jan 7];13:423-44. Available from: http://www.ncbi.nlm.nih.gov/pubmed/26569333

6. Sies H. The Concept of Oxidative Stress After 30 Years. Biochem. Oxidative Stress [Internet]. Cham: Springer International Publishing; 2016. p. 3-11. Available from: http://link.springer.com/10.1007/978-3-319-45865-6_1

7. Schieber M, Chandel NS. ROS function in redox signaling and oxidative stress. Curr. Biol. Cell Press; 2014.

8. Marseglia L, Manti S, D’Angelo G, Nicotera A, Parisi E, Di Rosa G, et al. Oxidative stress in obesity: a critical component in human diseases. Int. J. Mol. Sci. Multidisciplinary Digital Publishing Institute (MDPI); 2014;16:378-400.

9. An H, Du X, Huang X, Qi L, Jia Q, Yin G, et al. Obesity, altered oxidative stress, and clinical correlates in chronic schizophrenia patients. Transl. Psychiatry. Nature Publishing Group; 2018;8.

10. Roberts CK, Sindhu KK. Oxidative stress and metabolic syndrome. Life Sci. 2009;84:705-12.

11. Rani V, Deep G, Singh RK, Palle K, Yadav UCS. Oxidative stress and metabolic disorders: Pathogenesis and therapeutic strategies. Life Sci. Elsevier Inc.; 2016;148:183-93.

12. Tangvarasittichai S. Oxidative stress, insulin resistance, dyslipidemia and type 2 diabetes mellitus. World J. Diabetes [Internet]. 2015;6:456. Available from: http://www.wjgnet.com/19489358/full/v6/i3/456.htm 
13. Hurrle S, Hsu WH. The etiology of oxidative stress in insulin resistance. Biomed. J. Elsevier B. V.; 2017. p. 257-62.

14. Laakso M, Kuusisto J. Insulin resistance and hyperglycaemia in cardiovascular disease development. Nat. Rev. Endocrinol. Nature Publishing Group; 2014;10:293-302.

15. Bornfeldt KE, Tabas I. Insulin resistance, hyperglycemia, and atherosclerosis. Cell Metab. 2011;14:575-85.

16. Pizzino G, Irrera N, Cucinotta M, Pallio G, Mannino F, Arcoraci V, et al. Oxidative Stress: Harms and Benefits for Human Health. Oxid. Med. Cell. Longev. Hindawi Limited; 2017;2017.

17. Hermsdorff HHM, Puchau B, Volp ACP, Barbosa KB, Bressan J, Zulet MÁ, et al. Dietary total antioxidant capacity is inversely related to central adiposity as well as to metabolic and oxidative stress markers in healthy young adults. Nutr. Metab. (Lond). BioMed Central; 2011;8:59.

18. Martínez-Tomé M, Murcia MA, Mariscal M, Lorenzo ML, Gómez-Murcia V, Bibiloni M, et al. Evaluation of antioxidant activity and nutritional composition of flavoured dehydrated soups packaged in different formats. Reducing the sodium content. J. Food Sci. Technol. Springer India; 2015;52:785060.

19. Soccio M, Laus MN, Flagella Z, Pastore D. Assessment of antioxidant capacity and putative healthy effects of natural plant products using soybean lipoxygenase-based methods. An overview. Molecules. MDPI AG; 2018;23.

20. Haytowitz D, Bhagwat S. USDA Database for the Oxygen Radical Absorbance Capacity (ORAC) of Selected Foods, Release 2. US Dep. Agric. [Internet]. 2010;10-48. Available from: http://www.pureacaiberry.com/testimonials/ORAC_R2.pdf

21. Galasko DR, Peskind E, Clark CM, Quinn JF, Ringman JM, Jicha GA, et al. Antioxidants for Alzheimer disease: A randomized clinical trial with cerebrospinal fluid biomarker measures. Arch. Neurol. 2012;69:836-41.

22. Carocho M, Ferreira ICFR, Morales P, Soković M. Antioxidants and Prooxidants: Effects on Health and Aging. Oxid. Med. Cell. Longev. [Internet]. Hindawi Limited; 2018;1-2. Available from: https://www.hindawi.com/journals/omcl/2018/1472708/

23. Mirmiran P, Hosseini Esfahani F, Mehrabi Y, Hedayati M, Azizi F. Reliability and relative validity of an FFQ for nutrients in the Tehran Lipid and Glucose Study. Public Health Nutr. 2010;13:654-62.

24. Colarusso L, Serafini M, Lagerros YT, Nyren O, La Vecchia C, Rossi M, et al. Dietary antioxidant capacity and risk for stroke in a prospective cohort study of Swedish men and women. Nutrition. Elsevier Inc.; 2017;33:234-9.

25. Villaverde P, Lajous M, MacDonald C-J, Fagherazzi G, Bonnet F, Boutron-Ruault M-C. High dietary total antioxidant capacity is associated with a reduced risk of hypertension in French women. Nutr. J. 2019;18:31.

26. Rautiainen S, Levitan EB, Orsini N, Åkesson A, Morgenstern R, Mittleman MA, et al. Total antioxidant capacity from diet and risk of myocardial infarction: A prospective cohort of women. Am. J. Med. 2012;125:974-80. 
27. Vece MM, Agnoli C, Grioni S, Sieri S, Pala V, Pellegrini N, et al. Dietary total antioxidant capacity and colorectal cancer in the Italian epic cohort. PLoS One. Public Library of Science; 2015;10.

28. Bastide N, Dartois L, Dyevre V, Dossus L, Fagherazzi G, Serafini M, et al. Dietary antioxidant capacity and all-cause and cause-specific mortality in the E3N/EPIC cohort study. Eur. J. Nutr. Dr. Dietrich Steinkopff Verlag GmbH and Co. KG; 2017;56:1233-43.

29. Ellulu MS, Patimah I, Khaza'ai $H$, Rahmat $A$, Abed $Y$. Obesity and inflammation: the linking mechanism and the complications. Arch. Med. Sci. [Internet]. 2017;13:851-63. Available from: http://www.ncbi.nlm.nih.gov/pubmed/28721154

30. Fernández-Sánchez A, Madrigal-Santillán E, Bautista M, Esquivel-Soto J, Morales-González A, Esquivel-Chirino C, et al. Inflammation, oxidative stress, and obesity. Int. J. Mol. Sci. Multidisciplinary Digital Publishing Institute (MDPI); 2011;12:3117-32.

31. Nigro E, Scudiero O, Monaco ML, Palmieri A, Mazzarella G, Costagliola C, et al. New insight into adiponectin role in obesity and obesity-related diseases [Internet]. Biomed Res. Int. Hindawi Publishing Corporation; 2014 [cited 2017 May 2]. p. 658913. Available from:

http://www.ncbi.nlm.nih.gov/pubmed/25110685

32. Procaccini C, De Rosa V, Galgani M, Carbone F, La Rocca C, Formisano L, et al. Role of adipokines signaling in the modulation of T cells function. Front. Immunol. [Internet]. 2013;4:332. Available from: http://www.ncbi.nlm.nih.gov/pubmed/24151494

33. Aggarwal BB. Targeting inflammation-induced obesity and metabolic diseases by curcumin and other nutraceuticals. Annu. Rev. Nutr. [Internet]. NIH Public Access; 2010 [cited 2019 Jan 7];30:17399. Available from: http://www.ncbi.nlm.nih.gov/pubmed/20420526

34. Abdali D, Samson SE, Grover AK. How effective are antioxidant supplements in obesity and diabetes? Med. Princ. Pract. [Internet]. Karger Publishers; 2015 [cited 2019 Jan 7];24:201-15. Available from: http://www.ncbi.nlm.nih.gov/pubmed/25791371

35. Jager J, Grémeaux T, Cormont M, Le Marchand-Brustel Y, Tanti JF. Interleukin-1 $\beta$-induced insulin resistance in adipocytes through down-regulation of insulin receptor substrate-1 expression. Endocrinology. 2007;148:241-51.

36. Dal S, Sigrist S. The Protective Effect of Antioxidants Consumption on Diabetes and Vascular Complications. Diseases. MDPI AG; 2016;4:24.

37. Hussain T, Tan B, Yin Y, Blachier F, Tossou MCB, Rahu N. Oxidative Stress and Inflammation: What Polyphenols Can Do for Us? Oxid. Med. Cell. Longev. [Internet]. 2016;1-9. Available from: https://www.hindawi.com/journals/omcl/2016/7432797/

38. Solverson PM, Henderson TR, Debelo H, Ferruzzi MG, Baer DJ, Novotny JA. An Anthocyanin-Rich Mixed-Berry Intervention May Improve Insulin Sensitivity in a Randomized Trial of Overweight and Obese Adults. Nutrients [Internet]. 2019;11. Available from: http://www.ncbi.nlm.nih.gov/pubmed/31775396

39. Fraga CG, Croft KD, Kennedy DO, Tomás-Barberán FA. The effects of polyphenols and other bioactives on human health. Food Funct. Royal Society of Chemistry; 2019;10:514-28. 
40. Papada E, Kaliora AC. Antioxidant and anti-inflammatory properties of mastiha: A review of preclinical and clinical studies. Antioxidants. 2019.

41. Bahadoran Z, Golzarand M, Mirmiran P, Shiva N, Azizi F. Dietary total antioxidant capacity and the occurrence of metabolic syndrome and its components after a 3-year follow-up in adults: Tehran Lipid and Glucose Study. Nutr. Metab. 2012;9:1-9.

42. Azzini E, Giacometti J, Russo GL. Antiobesity Effects of Anthocyanins in Preclinical and Clinical Studies. Oxid. Med. Cell. Longev. Hindawi; 2017.

43. Mopuri R, Islam MS. Medicinal plants and phytochemicals with anti-obesogenic potentials: A review. Biomed. Pharmacother. Elsevier Masson SAS; 2017;89:1442-52.

44. Siddiqui AH, Gulati R, Tauheed N, Pervez A. Correlation of waist-to-hip ratio and oxidative stress in patients of acute myocardial infarction. J. Clin. Diagnostic Res. 2014;8:4-7.

45. Raja Kumar S, Mohd Ramli ES, Abdul Nasir NA, Ismail NHM, Mohd Fahami NA. Preventive Effect of Naringin on Metabolic Syndrome and Its Mechanism of Action: A Systematic Review. Evidence-based Complement. Altern. Med. Hindawi Limited; 2019.

46. Yannakoulia M, Ntalla I, Papoutsakis C, Farmaki AE, Dedoussis G V. Consumption of vegetables, cooked meals, and eating dinner is negatively associated with overweight status in children. J. Pediatr. 2010;157:815-20.

47. Karfopoulou E, Brikou D, Mamalaki E, Bersimis F, Anastasiou CA, Hill JO, et al. Dietary patterns in weight loss maintenance: results from the MedWeight study. Eur. J. Nutr. Dr. Dietrich Steinkopff Verlag GmbH and Co. KG; 2017;56:991-1002.

48. van der Schaft N, Schoufour JD, Nano J, Kiefte-de Jong JC, Muka T, Sijbrands EJG, et al. Dietary antioxidant capacity and risk of type 2 diabetes mellitus, prediabetes and insulin resistance: the Rotterdam Study. Eur. J. Epidemiol. Springer Netherlands; 2019;34:853-61.

49. Kim K, Vance TM, Chun OK. Greater Total Antioxidant Capacity from Diet and Supplements Is Associated with a Less Atherogenic Blood Profile in U.S. Adults. Nutrients. Multidisciplinary Digital Publishing Institute (MDPI); 2016;8.

50. Casas-Grajales S. Antioxidants in liver health. World J. Gastrointest. Pharmacol. Ther. Baishideng Publishing Group Inc.; 2015;6:59.

51. Savu O, Ionescu-Tirgoviste C, Atanasiu V, Gaman L, Papacocea R, Stoian I. Increase in Total Antioxidant Capacity of Plasma despite High Levels of Oxidative Stress in Uncomplicated Type 2 Diabetes Mellitus. J. Int. Med. Res. SAGE Publications; 2012;40:709-16.

52. Petelin A, Tedeschi P, Maietti A, Jurdana M, Brandolini V, Pražnikar ZJ. Total Serum Antioxidant Capacity in Healthy Normal Weight and Asymptomatic Overweight Adults. Exp. Clin. Endocrinol. Diabetes. 2017;125:470-7. 